\title{
26384 - ALPHA5-GABA-ARS ARE NOT REQUIRED FOR MEMORY IMPAIRMENT BY ETHANOL IN MICE
}

\author{
Loren Martin MSc, Bonnin Robbert, BSc; Oh Bonin, ; Orser Beverley, \\ University Of Toronto, Toronto, ONTARIO, Canada
}

INTRODUCTION: Ethanol has been used for centuries as an analgesic and anesthetic. The receptors and molecular mechanisms underlying the behavioral effects of ethanol remain elusive. ã-aminobutyric acid type A receptors (GABA-ARs) mediate the majority of synaptic and tonic inhibitory conductances in the brain[1]. GABA-ARs contain an ethanol binding site and thus, are attractive candidates for mediating the intoxicating effects of ethanol. Previous reports showed that a tonic inhibitory conductance generated by GABA-ARs that contain the ä; subunit in dentate gyrus granule cells was highly sensitive to low concentrations of ethanol $(30 \mathrm{mM})[2]$. A tonic conductance is also generated by GABA-ARs containing the á;5 subunit (á;5GABA-ARs) in CA1 hippocampal pyramidal neurons [3]. These á;5GABA-ARs have been implicated in the amnestic properties of anesthetics [4] and the rewarding properties of ethanol [5]. We used complementary electrophysiological and behavioral strategies to test the hypothesis that ethanol increases a tonic conductance in hippocampal pyramidal neurons via activation of á;5GABA-ARs and this action contributes to amnestic effect of ethanol. METHODS: The animal care committee at the University of Toronto approved the experimental protocols. To determine whether low concentrations of ethanol increased the tonic conductance in hippocampal pyramidal neurons, whole-cell currents were recorded from cultured hippocampal neurons from Swiss White mice. In other experiments, contextual and delay fear conditioning was used to study ethanol effects on memory performance in wild-type (WT) and á;5 null mutant mice (á;5-/-). Results are presented as mean \pm s.e.m. and groups were compared using analysis of variance $(\mathrm{P}<0.05)$.

RESULTS: Ethanol applied at high ( $300 \mathrm{mM}$ ) but not low concentrations potentiated a tonic current recorded in hippocampal neurons. Ethanol administered at low or medium doses of ethanol $(0.5$ or $1 \mathrm{~g} / \mathrm{kg}$ ) failed to impair memory performance in both genotypes whereas a higher dose $(1.5 \mathrm{~g} / \mathrm{kg})$ caused a similar impairment in WT and á;5-/- mice. DISCUSSION: In vitro results showed that á;5GABA-ARs are not sensitive targets for low concentrations of ethanol. The in vivo behavioral studies showed that á;5GABAARs are not necessary for memory impairment by ethanol. Deletion of the á;5 subunit gene was not associated with altered ethanol sensitivity for memory impairment.

Together the results suggest that á;5GABA-ARs do not contribute to amnestic properties of ethanol.

\section{REFERENCES:}

1. Trends Neurosci. 2004 May;27(5):262-9.

2. J Neurosci 2004 24(38): 8379-82.

3. Proc Natl Acad Sci U S A. 2004 101(10): 3662-7.

4. J Neurosci. 2004 Sep 29;24(39):8454-8.

5. Alcohol Clin Exp Res. 2005 29(8): 1390-401. 